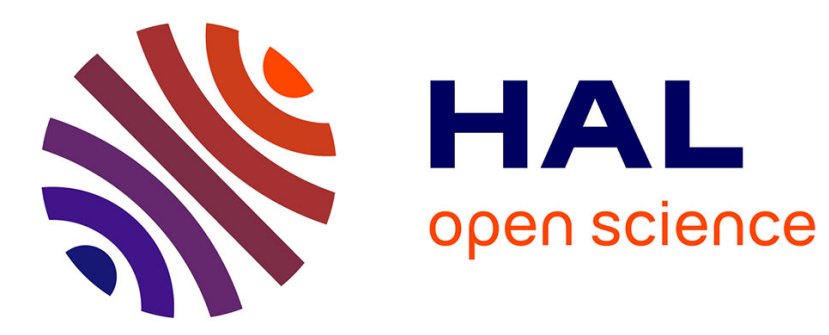

\title{
When union strategy meets business strategy: The union voucher at Axa
}

Rémi Bourguignon, Mathieu Floquet

\section{To cite this version:}

Rémi Bourguignon, Mathieu Floquet. When union strategy meets business strategy: The union voucher at Axa. Business History, 2019, 61 (2), pp.260-280. 10.1080/00076791.2017.1368491 . hal01654637

\section{HAL Id: hal-01654637 https://hal.science/hal-01654637}

Submitted on 7 Dec 2017

HAL is a multi-disciplinary open access archive for the deposit and dissemination of scientific research documents, whether they are published or not. The documents may come from teaching and research institutions in France or abroad, or from public or private research centers.
L'archive ouverte pluridisciplinaire HAL, est destinée au dépôt et à la diffusion de documents scientifiques de niveau recherche, publiés ou non, émanant des établissements d'enseignement et de recherche français ou étrangers, des laboratoires publics ou privés. 


\title{
When union strategy meets business strategy:
}

\section{The union voucher at Axa}

\author{
Rémi Bourguignon \\ IAE Paris 1 Panthéon-Sorbonne (Sorbonne Business School), France \\ Mathieu Floquet \\ Université de Lorraine, Nancy, France
}

Rémi Bourguignon is an assistant professor at Sorbonne Business School - IAE de Paris, and an associate researcher at Cevipof - Sciences Po (CNRS-UMR7048). His research focus is on employment relations, trade-unions and organisational democracy.

8 bis rue de la Croix Jarry

75013 Paris

France

Phone +33 689904774

bourguignon.iae@univ-paris1.fr

Mathieu Floquet is an assistant professor at the Université de Lorraine (ISAM-IAE Nancy, CEREFIGE). His research focus is on management history with a special interest in French labor history.

25 rue Baron Louis

CS 10399

54007 Nancy Cedex

Phone +33679561375

Mathieu.Floquet@univ-lorraine.fr 


\begin{abstract}
In the 1980s, the French reformist union CFDT and insurance company Axa tested the union voucher. This was a novel solution for the union branch inside the company to address financial difficulties, broaden its membership base and generate new resources. The union voucher is a tool that provides unions with company funding: the company distributes vouchers to employees on an annual basis; employees then allocate the voucher (or not) to the union branch of their choice. The voucher system thus combines company financing and individual employee choice. Axa adopted the system in the early 1990s. Axa's decision can ultimately be explained by its external growth strategy and because it needed to preserve a favourable social climate during a period of intense restructuring. This article traces the history of the union voucher and assesses Axa's experience.
\end{abstract}

\title{
Keywords
}

Industrial relations, French unions, Union finance, Axa, CFDT.

\section{Abbreviations}

CFDT: $\quad$ Confédération française démocratique du travail

CFE-CGC Confédération française de l'encadrement - Confédération générale des cadres

CFTC Confédération française des travailleurs chrétiens

CGT Confédération générale du travail

CNPF Conseil national du patronat français

FO Force Ouvrière

REPONSE Enquête Relations professionnelles et Négociations d'entreprise (survey on industrial relations and workplace negotiations) 
Numerous studies in labour history underline the specific characteristics of industrial relations in France. More than in comparable countries, unions in France are politicised; the explanation for this can be found in the French political regime. Lipset ${ }^{1}$, for example, observed that France is characterised by an aristocratic power structure that leaves little room for union participation in the democratic regime. Such studies in labour history analyse unionism in terms of ideologies and the development of political regimes in different countries but only touch upon the interactions of unions with the world of business. However, as shown by Philippon ${ }^{2}$ and argued by Magnusson ${ }^{3}$, it is worth comparing studies in both the history of labour and the history of business. The bon de financement or union voucher, a mechanism fund trade-unions and encourage unionisation inside the company, was tested and adopted by the French insurance company Axa at the beginning of the 1990s. The case of the union voucher offers a significant illustration in business and labour history in favour of cooperation. The union voucher experiment is regularly presented as a social reform initiated by a modernist employer, Claude Bébéar. As French social history unfolded from the Second World War (WWII), through the impassioned debates of the 1960s to the 1990s, the influence of the modernist trend and its representatives was visible to employers, unions and French State.

However, the present article offers another understanding of the voucher's emergence by examining its microhistory. This view reveals the voucher as a concrete tool, and specifically highlights the business side of the story. The union voucher was not just the result of an ideological programme implemented by a modernist employer; it was also a pragmatic solution to issues faced both by unions and the Axa company. The voucher's emergence can be explained by a specific configuration where the wishes of the CFDT union coincided with those of the employer, namely the Axa insurance company. On the one side, the CFDT was seeking new members and new financial resources. On the other, Axa needed to preserve a 
good social climate in a period of intense restructuring. In a system of industrial relations where the law facilitates the establishment of unions in the workplace, the question for the employer is not how to "do without" unions but how to "do with" them. In this situation, Axa hoped that the union voucher, by enabling individual worker choice, would be a way of depoliticising unions and strengthening reformist unions to the detriment of militant. The union voucher still exists at Axa, and its terms and conditions have remained the same since its adoption in 1990. In 2014, it provided $€ 517 \mathrm{~K}$ of funding across all Axa’s union branches: the total amount budgeted ${ }^{4}$ by the company was $€ 1,020 \mathrm{~K}$ but only half the workers allocated their voucher to a union. The collective agreement specifies that the funds allocated via the union voucher should be used to obtain new material resources, particularly financing the mobility and training of union representatives, acquiring new equipment or communicating to employees.

To complete our historical investigation, we used two main sources. Firstly, we collected archival documents from the $\mathrm{CFDT}^{5}$ (meeting reports, working documents, draft agreements, etc.); secondly, we interviewed key protagonists of the experiment ${ }^{6}$. Although Axa had no archives about the union voucher, we overcame this by examining the press and secondary sources on the French insurance industry in the 1980s. In this article, we first look at French social history to show the dynamics of the modernist trend from the WWII to the 1990s (1) before turning to the microhistory of the union voucher. In the second section, we then present the background of industrial relations in French companies and corresponding unionprevention strategies (2). The next two sections present the history of the union voucher in the light of the specific interests of both the CFDT (3) and Axa (4) in adopting it. We conclude the study (5) by acknowledging the complementary nature of labour and business history in understanding the adoption of the union voucher: the union voucher clearly represents a certain conception of industrial relations, that of the reformist movement. Its implementation, 
however, largely depended on business issues. Finally, we add our names to the call for crossfertilisation between the history of labour and the history of business. 


\section{Box 1. The Union Voucher}

The union voucher system, similar to an education or housing voucher in the United Kingdom, is a funding model that combines a subsidy mechanism with market logic. In the union voucher system, the funding is covered by the employer but the allocation of funds among the various unions represented in the company is decided by workers' individual choice. In this way, the tool stimulates market mechanisms, and unions are encouraged to deliver meaningful services, whether individual or collective. In concrete terms, the voucher is internal to the company. Once a year, the employer gives each employee a voucher which may be allocated (or not) to union branches established in the company (here, Axa). At the end of the collection period, the union branches submit all the vouchers received to the company (employees remaining anonymous) and, in return, receive the corresponding funds. Resources obtained through this system are used for union work within the company ${ }^{7}$. The following year, the union branches are required to issue a public report on the use of the funds.

This mechanism for union funding, conceptualized within the CFDT in the 1980s, was implemented in Axa's workplaces in France from 1990 and conclusively adopted in 1992. The union voucher is now in use in a number of other organisations such as cancer institutes and social security centres but remains of little weight despite the fact that institutional reports devoted to encouraging social dialogue and the regeneration of French unionism ${ }^{8}$ regularly assess it as belonging to best practice. In October 2015, the Prime Minister himself considered extending the mechanism to all companies in France and in February 2016, the reformist employer, Louis Gallois ${ }^{9}$, grabbed media attention by championing the union voucher. 


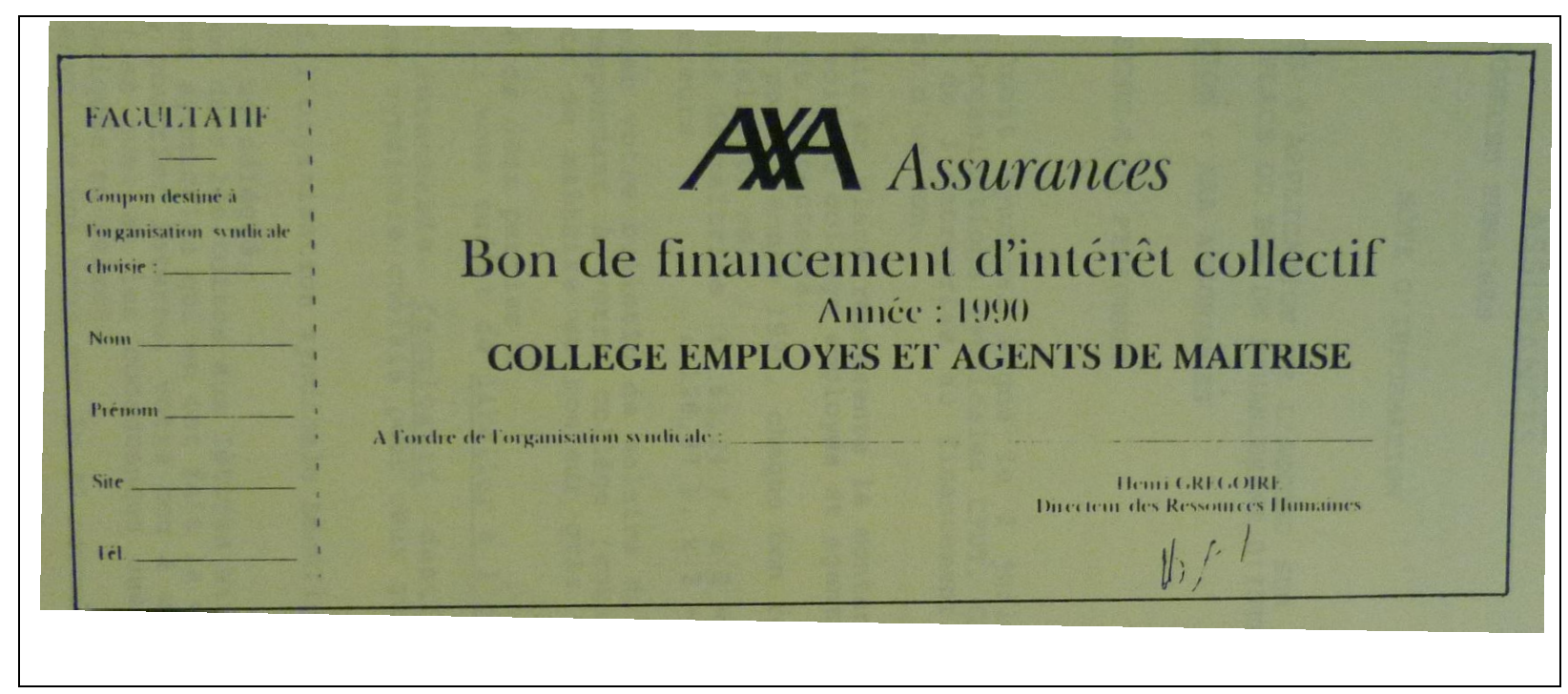




\section{The rise of a modernist trend in France after the Second World War.}

The union voucher can be viewed as the work of modernist employers convinced that economic and social progress should go hand in hand. In any case, this was the view generally accepted in the public debate of 1990 when Claude Bébéar, head of the Axa company, started to test it. The media presented the union voucher as initiated by Bébéar himself. The headline of Le Figaro on $3^{\text {rd }}$ July 1990 ran: "Axa turns on the charm for trade-unions. The insurer just signed an 'innovative' agreement with workers' unions", while the newspaper Le Quotidien de Paris gave the union voucher experiment an ideological interpretation: "Claude Bébéar (Axa): Long live social-democracy!". More generally, the media underlined the divisions among both employers and unionists that followed the agreement, as shown in this headline from Liberation on $4^{\text {th }}$ July: "The union voucher shakes trade-unions and employers".

In fact, identifying a "modernist" or "reformative" trend ${ }^{10}$ provides a well-established interpretative framework for understanding French social history during the $20^{\text {th }}$ century. Moss showed that a modernist trend, essentially comprised of top civil servants and intellectuals, began to take shape from the 1960 s to promote a contractual approach to the employer/employee relationship as opposed to the class antagonism which continued to characterize French industrial relations at that time. The question of democracy in the workplace is relatively deep-rooted in France as in most democratic countries; the question gained importance with the economic and social reforms following the Second World War ${ }^{11}$. The creation of the works council in $1945^{12}$ and the regulation of collective bargaining per sector in 1950 illustrate this democratisation, but these reforms did not produce the expected effects in terms of labour/management cooperation. After WWII, the CGT, the main tradeunion in France, adopted Marxism and class struggle as its official doctrine ${ }^{13}$ and its attitude towards reforms was more than ambiguous as shown by Chatriot in his writing about national negotiation in $1950^{14}$. For their part, some employers remained very reluctant to strengthening 
trade-unions, although it is important not to exaggerate the employers' stand which was less opposed to employees' representation than desirous of promoting reformist unions. Moss underlines that the $\mathrm{CNPF}^{15}$ was not closed to all forms of reform but only to those likely to reinforce class unionism, an observation shared by Fridenson ${ }^{16}$. A publication by François Bloch-Lainé in 1963 constitutes a key moment in the history of this modernist trend ${ }^{17}$. The author, a senior civil servant, presented an ambitious programme to transform relationships in the workplace, in particular promoting compulsory union dues to stem the fall in unionisation rates. This book was very successful within the modernist trend but caused negative reactions among employers and unions alike ${ }^{18}$. It then became clear that the modernist trend, despite its representation in various spheres, had little impact on unions and employers. The reformists' main strategy was thus to influence political power in order to introduce reforms through legislation. However, lack of organised support prevented any government from making significant legislative progress and the events of 1968 mark a turning point in the history of this trend.

A number of employers, aware of the gravity of the 1968 strikes and the threat they posed to the French economy, began to organise to reform the French social model ${ }^{19}$. A first and remarkable initiative was the creation in 1970 by a few businessmen of an association, Entreprise et Progrès, enabling advocates of modernising business and the social model to spark public debate. Two years later, in October 1972, Antoine Riboud, the famous head of BSN, spoke at the CNPF convention. In his speech, he stood for the need for a plan catering to both the economic and social aspects of business, claiming "we took too long to recognise trade-unions as employees' chosen representatives. We should not make that mistake again!”. In suggesting that strengthening the trade-unions would mean being able to negotiate with legitimate representatives, he was reaffirming the consistent view of the modernists: in other words, economic and social issues should be resolved through collective bargaining. 
During this time, the reformist trend also gained traction in the union camp. Fridenson ${ }^{20}$ warns against a simplistic classification according to which some trade-unions are revolutionary while others are reformist. In reality, the division runs through all these organisations and no trade-union since WWII can systematically oppose social reforms because unions only survive if they obtain results. The fact remains that in the 1970s the CFDT took an official reformist turn. In 1976, Edmond Maire, then CFDT Secretary General, initiated a refocusing strategy by emphasising his organisation's independence of the political agenda. He abandoned waiting for social change through political power, even with the prospect of a leftist victory in the 1978 elections. The report drafted by leader of the CFDT Jacques Moreau $^{21}$ in 1978 detailed the new union strategy. One of its main points was giving greater priority to negotiation than recourse to law for reforming the economic system ${ }^{22}$. A central point in the new strategy was to strengthen collective negotiation at the company level. Historically, French unions were organised on a trade level through federations, and collective negotiation was largely sectorial. They can thus be compared to German or Nordic unions but are fundamentally different to British unions which are organised at the workplace level. By emphasising collective negotiation at the company level and the need to unionise workers, the CFDT broke this historical organisation. Although the CFTC and CFE-CGC, commonly associated with the CFDT and the reformist movement, did not oppose this view, the same was not true for the CGT or FO. These two organisations had a more radical view on collective negotiation. In their eyes, favouring the workplace level would be dangerous and they preferred to maintain the central role of federations and confederations which provided a means of protecting against depoliticisation and a way of limiting competitive pressure on negotiation.

At the beginning of the 1980s, the modernist trend had representatives among both the unions and the employers, and one of its rising stars was Claude Bébéar, head of Axa. It was thus 
natural to view the adoption of the union voucher through negotiations between the CFDT and Claude Bébéar as a reformist initiative designed to spark public debate. The union voucher raised the question of how the workplace should be viewed and what exactly the place of collective bargaining should be. Such interpretations are certainly meaningful, but too wide-ranging for fully understanding the dynamics behind the emergence of the union voucher. Further, this interpretation emphasises a social and ideological approach to company decisions, but neglects business rationales and hence is not convincing. Why, for example, did other modernist employers fail to follow Bébéar's example in replicating the tool? By retracing the microhistory of the union voucher, the present article endeavours to show that the union voucher is not only the logical translation of an ideological program but also a pragmatic answer to managerial issues for both parties - for unions: to gain new sources of funding, and for employers: to pour oil on industrial relations in view of a wave of restructuring.

We argue that while modernist ideology played a key role, it was a necessary but insufficient condition explaining the emergence of the union voucher as social innovation in the company. In our view, it was also the result of a specific configuration that includes industrial relations and managerial issues. We now move from a macro analysis of the social history to micro observation at the company level. We therefore begin the next section by introducing the rules of industrial relations in French companies before turning to a more specific analysis of the union voucher experiment in sections 3 and 4. 


\section{Union-prevention strategies in French companies}

The conditions for unionising a workplace and funding unions have a great impact on a firm's business environment. In the specific case of France, the undemanding conditions granted to certain unions for setting themselves up in companies may well result in union branches that are poorly representative and highly politicised. Historically, this has reinforced management's mistrust of unions and led to efforts to weaken them, either by bypassing them or by diverting them from their role of contestation. The union voucher system tested and eventually adopted at Axa is atypical since it consisted in providing unions with financial support in order to influence their internal governance and ultimately make them more representative and more useful for business.

\section{a. Specifics of French unionism and system of industrial relations}

The specific features of the French system of industrial relations are well known: France has the lowest rate of unionisation in the OECD countries, combined with the highest union coverage, politicised unionism and confrontational labour-employer's relations. To understand the interactions between business and this system of industrial relations, we must put macrosocial questions such as ideology and political systems aside, and consider the concrete modes of union action instead, particularly in the workplace.

In English-speaking countries, beyond the institutional specifics, setting up a workplace union depends upon a vote by the workers themselves. If the workers reject unionisation, the firm remains union-free and the negotiation of rules underlying the employment relationship are at the management's discretion. As shown by Freeman and Medoff, an employer wishing to prevent a union from being established might adopt "union-prevention" strategies to influence workers' votes: an acceptable social package, anti-union propaganda, a control of voting modalities or other less legitimate practices discriminating against unions ${ }^{23}$. The situation in 
France is complex due to the rules for establishing unions. Between 1968 and 2008, five unions, identified at a national level by the State, were irrefutably presumed to be representative. This allowed them to unilaterally unionise firms with a minimum of 50 workers. Under this system, a local union affiliated to one of the five national organisations has no obligation to obtain workers' support ${ }^{24}$. French unions are thus widespread in firms. According to the French Statistics Office's REPONSE survey, a union branch exists in 95\% of firms with at least 300 workers ${ }^{25}$.

In addition to ease of union establishment, union funding has also gradually contributed to the distance between unions and workers. French unions suffer from free-riders, since all workers benefit from union action whether they are unionised or not. This state of affairs explains a paradoxical situation in France: while 98\% of workers are covered by a union contract, only $8 \%$ of them are actual union members ${ }^{26}$. To survive, then, unions diversified their sources of revenue, particularly resources from employers... Revenue obtained independently, without worker support, emphasised the gap between union leaders and workers in the workplace. Not only do unions not need workers' support to unionise a workplace, they don't even need the support to obtain resources. It follows that the representativeness of French union leaders is regularly contested by employers who do not wish to negotiate with them. A system such as this is thus highly likely to end up promoting politicised union militants. Employers thus risk being forced to negotiate with unions that demand restrictive practices that do not satisfy workers or, worse still, must deal with unions that actively fuel social conflict for political reasons.

\section{b. Employers' strategies to weaken unions in France}

Each system of industrial relations has different rules, so it should come as no surprise that employer attitudes towards unions differ between English-speaking countries and France. 
While in English-speaking countries, particularly the United States, employers try to "do without" unions by influencing the workers' votes, employers in France have to "make do with" unions that are in a dominant position. In this situation, instead of using classic union avoidance strategies, the main managerial strategies consist in marginalising unions or diverting them from their role of contestation ${ }^{27}$. For example, managerial strategies can take advantage of the laws that make it easy to set up a union and encourage the creation of unions with more cooperative members, thus challenging and marginalising the more militant unions. The Schneider \& Cie case in France ${ }^{28}$ and Taff Vale case in the United Kingdom ${ }^{29}$ in the early 1900s are representative of this strategy. In both cases, the management tried to break a strike, weakening the union by creating a counter-union. While French multi-unionism can be used to set unions against each other during collective bargaining with employers, the same marginalisation strategy has also been used to reach collective agreements that employers find acceptable. Other strategies aim to divert unions from contesting or gaining control over management, by confining them to the administration of social and cultural activities. The Works Council, or "comité d'entreprise" in France, is responsible for various activities: it has a social function, administering the canteen, travellers' checks, luncheon vouchers, etc., and an economic function through which employees' representatives participate in the firm's management. These two functions are quite different and in fact have conflicting interests, as mentioned by legislators during debates about works council legislation in $1944^{30}$. We thus see works councils that tend to prioritise the social over the economic function, and employers can encourage this by giving substantial funds for social activities ${ }^{31}$. Diverted from contestation and company management, unions concentrate on less problematic issues and preserve managerial discretion, an equilibrium known as paternalistic management.

These two types of strategy - marginalising unions or diverting them from militant political action - are representative of an industrial relations policy that aims to "make do with" unions 
rather than avoid them, while at the same time weakening them in collective bargaining. On the contrary, the union voucher is a managerial tool that strengthens unions and influences their positioning, particularly by depoliticising them.

\section{c. The union voucher, a managerial tool to influence union governance}

Regarding these institutional characteristics, the union voucher is definitively not just a source of funding but changes the very nature of industrial relations in the workplace. To increase or simply maintain their resources, union branches must forever adapt their services, since dissatisfied workers can sanction them by not allocating the voucher the following year. So the voucher is not only a mechanism for providing unions with resources, it also transforms internal union governance by placing union leaders under workers' control. Finally, it activates market forces in a context, where, as seen above, a membership market is lacking and where unions are far too independent of workers. From the employer's point of view, the mechanism provides an alternative strategy with respect to unions. Rather than marginalising or diverting unions, the voucher influences their functioning, making them truly representative and more useful for business.

It is therefore worth revisiting its origins and understanding the conditions under which it emerged. History shows that the voucher system did not result from a theoretically coherent program, but gradually arose at the national level of the CFDT, as a pragmatic answer to the union's funding crisis in the 1970s and 1980s. In fact, it was tested at Axa, whose top manager saw it as an opportunity to pacify labour relations and as a lever for securing the company's plan for transformation through external growth. 


\section{The union voucher at the CFDT: a source of funding and increased membership?}

Seeking to increase the union's financial resources and attract membership was the subject of much discussion at the CFDT between 1982 and 1986. From these discussions resulted the union voucher system. From 1987 onwards, the union worked on ways of setting up and testing the union voucher system.

The debate about the financial issue was opened up to all members in 1982. An article in the CFDT internal magazine, for example, called for input. For the first time, the union voucher appeared as a "kind of tax paid by companies on their funds or through levies on salaries, that is disbursed for union operations" ${ }^{32}$. After the article, however, the debate was shelved. A government initiative re-launched it in $1984^{33}$. On the government's request, the CFDT set up a working party to propose a tool providing the unions with new official resources ${ }^{34}$. The CFDT, like other unions, was the victim of free riders: the union's bargaining benefited all employees but few were actually union members. Union bargaining requires resources and with the decrease in membership, the unions' financial position was deteriorating.

The CFDT solution appeared in the form of a union voucher useable by employees and funded by employers. Workers would be able to send their voucher to any union represented in the company. This solution strengthened the relationship between workers and union representatives ${ }^{35}$.

From being a means of funding, the union voucher gradually became a way of broadening the membership base. The working party finally adopted the solution in 1985. It had certain advantages: it ensured the unions' independence from the company, workers' freedom to use the voucher or not and offered the possibility of recruiting new members. Above all, however, the solution provided fresh resources for a union helplessly watching as membership, and consequently, subscriptions decreased. 
At the end of 1985, the government was in bad shape, and the 1986 parliamentary elections were going to be difficult for the Left. The project was leaked to the press and in December 1985, the Minister of Labour announced that there would be no discussion on the issue of financial resources for the unions.

Nevertheless, the CFDT Executive Committee did not abandon the project, instead deciding to negotiate with certain companies. But the union voucher issue was almost dropped from the various CFDT bodies' agenda and the working party appeared to be dissolved. The file was transferred to union representatives at a level closer to the companies and especially to the federation of services sector. D. Orsal, negotiator for the CFDT on the voucher agreement, confirms this: "The idea of the confederation was to test the water and find a company that could agree with the operation: give a value to the voucher that employees would receive and hand over to the unions of their choice."36. The insurance sector was held by the Federation of the CFDT service sector and insurance companies seemed an ideal ground to test the voucher: "It was the period of concentration in the insurance industry and the CFDT was the biggest or second biggest union in all the insurance companies. We were very progressive. The insurance business was homogenous with no internal political problems and there was a lot of bargaining. This was because of rich companies that had to reorganize their organisations" In particular, the Federation detected an interest for this tool at the insurance company «Les Mutuelles Unies" which was turning into a group called Axa. The company management seemed in favour of the role employees played in using this tool: "the originality of the voucher was the place of the employee, which greatly pleased the company"38. In 1987 , discussions led to a first version of the agreement that we found in the CFDT archives ${ }^{39}$. Axa had even allocated a budget for the voucher, but restructuring was forging ahead with the purchase of a new company in 1986: "At the time everything was ready, Axa had merged four companies $[\ldots]$ and the union voucher fell by the wayside" 40 . 
In 1989, the project was back on Axa's agenda, but the confederation seems to have abandoned it once again: "Kaspar [CFDT General Secretary] had other concerns and the discussion was dragging on". Minor issues such as deciding the differential in voucher value among various levels of employee (management versus non-management employees) stalled progress. C. Bébéar was impatient for the tool to be implemented: "He [C. Bébéar] was irritated and he said that we had two months to conclude" ${ }^{41}$.

The negotiators had to convince the CFDT General Secretary of the agreement's relevance despite the fact it was the confederation itself which had thought up the tool.

The final hurdle was to convince other unions to sign the agreement. The other union representatives learned that the agreement had been negotiated directly between the CFDT and Axa's management. Two unions (CFTC and CGC) agreed to sign, two others (CGT and FO) refused.

Finally, the agreement was signed on 2 July 1990: "C. Bébéar demanded a signature with great pomp. There was a large rostrum with the signatories for the company, the boss of the CFTC, Jean Bornard, the General Secretary of CGC, Paul Marchelli [and Jean Kaspar, for the CFDT]. The press was invited to attend the event. After that, there was an extraordinary press campaign. For three days, we were in all the papers" ${ }^{42}$. 


\section{Axa: Restructuring in a peaceful social climate}

Axa joined the union voucher project in 1987 when the government had abandoned it. Axa, a young insurance company, resulted from the purchase of several companies. Claude Bébéar, its iconic head, was the embodiment of Axa. Even though Axa is improperly credited with its origin, the union voucher became a symbol of the company's social strategy. In reality, as we have seen, Axa jumped on board the project 6 years after the CFDT's first discussions. Axa seemed to adopt the system as a response to its search for a peaceful social climate during a phase of restructuring. But the recurring question is how and why? At this stage, based on interviews with key protagonists and prior research on the firm's expansion, we show that adopting the union voucher can be explained through Axa's strategy for external growth throughout the 1980s and 1990s. In the mind of Axa's management, the company had to create a tool that would enable union branches to bargain, but in such a way that they would depend on employees, not on the union and its confederation. This is precisely the role played by the union voucher.

It should be remembered that the company named Axa by C. Bébéar in 1984 originated as a mutual insurance company in Rouen that was to become "Les Mutuelles Unies", a company with a market share of less than 1\%. C. Bébéar joined the company in 1958 after studying at the French École Polytechique ${ }^{43}$, and held various management positions ${ }^{44}$. 1975 was a turning point for both the company and C. Bébéar's career. As C. Bébéar explained, he "rose to power in this small mutual insurance company, throwing out the previous head after a strike when employees occupied the company for five weeks, using violence.” This social crisis was significant for C. Bébéar: the company's social context during this episode showed the importance of industrial relations in an insurance company where the absence of traditional shareholders enabled him to become company director thanks to a social conflict ${ }^{45}$. 
As a consequence, and to guard against future social risk, he mandated his human resources director, Pierre Gardes, to implement social innovations such as flexitime, distance working, part-time work, quality circles, etc.

C. Bébéar moulded the company organisation along these lines up until the changes in the insurance sector during the 1980s. Indeed, 1987 was the starting point of discussions between Axa and CFDT about the union voucher, but also the year that marked the beginning of the privatisation and liberalisation of prices in the French banking and insurance sector ${ }^{46}$ led by the liberal government of Jacques Chirac $(1986)^{47}$. Discussion on the creation of a single European insurance market (effective 1992) was another illustration of the state of the sector in the late 1980s. Finally, the stock market crash of October 1987 provided Axa with new opportunities (for example, La Compagnie du Midi, the AGP holding company, requested Axa's intervention in 1988 to counter the Italian insurance company Generali's entry into its stock during the crash). For Axa and other insurance companies, the issue was clear: a wave of concentration was inevitable ${ }^{48}$. Insurance companies needed to reach a critical size to ensure their survival in a sector of fast-moving technology and increasing investment. In this situation, the mutual insurance company accelerated its strategy for external growth both in France and abroad - as did most multinational insurance companies ${ }^{49}$. After the acquisition of Drouot (1983) and Providence (1986), Axa acquired La Compagnie du Midi (AGP) in 1989, Equitable (1992) and UAP (1987). Axa thus became France's biggest property and casualty insurance company (Table 1).

Table 1. From Mutuelles Unies to Axa, revenue growth from 1980 to 1992

\begin{tabular}{c|c|l}
\hline Year & $\begin{array}{c}\text { Revenue } \\
\text { (in billion euros) }\end{array}$ & Growth of the company scope \\
\hline 1980 & 0.2 & Mutuelles Unies \\
\hline 1983 & 1.3 & Acquisition of Drouot \\
\hline 1984 & & Creation of Axa \\
\hline
\end{tabular}




\begin{tabular}{c|c|l}
\hline 1986 & 3.4 & $\begin{array}{l}\text { Acquisition of Providence and Secours } \\
\text { becoming Présence }\end{array}$ \\
\hline 1989 & 7.3 & Acquisition of La Compagnie du Midi (AGP) \\
\hline 1992 & 18.3 & Acquisition of Equitable \\
\hline
\end{tabular}

Source: Villette (2002)

The growth of Mutuelles Unies was impressive. This small provincial company purchased firms several times its size. In 1981, for example, Drouot was France's second largest private insurance company when Mutuelles Unies purchased a company more than one and a half times larger than itself. However, the operation was complex: it lasted for a year and involved legal action. Drouot's management disagreed with the operation, preferring the offer from Bouygues Construction Company which would have preserved Drouot's independence. The group employed 4,500 employees compared to 1,850 before the purchase. But employees of both companies were worried: those at Drouot feared for their jobs and those at Mutuelles Unies worried about the firm's survival. Drouot was in deficit, heralding a possible company failure. In 1982, for example, Drouot generated a net loss of -225 million Francs (See Table 2) where Mutuelles Unies generated 89 million. In 1985, the group published its first financial statements under the Axa name: net income had increased by $80 \%$ and Drouot was once again making a profit. A few weeks later, C. Bébéar launched a new attack to buy the La Providence company. The stock market battle lasted nearly 10 months from November 1985 to May 1986 ending with Axa's victory. The purchase of La Providence consolidated Axa as the largest private non-life insurance company in France. Following this, C Bébéar went out again and took control over La Compagnie du Midi thanks to a game of alliances and misalliances with Generali (the Italian insurance leader).

All the above purchases incurred hostility towards Axa from the purchased companies' management. In the 1980s in fact, not a single one of Axa's purchases in France was a friendly takeover. 
The battle for size in the insurance industry is not unique to France. In the 1980s, the insurance industry was facing major structural modifications. Academic studies of the mid1980s show that new technology provided insurance companies with optimal gains in productivity but required changing the workforce structure. To take full advantage of the gains in productivity, insurance companies had to scale down the number of administrative staff in favour of managers ${ }^{50}$. The introduction of new technology opened the floodgates to new economies of scale ${ }^{51}$, going hand in hand with a wave of M\&As in all developed countries. While target companies tended to display poor performance before the purchase ${ }^{52}$, the strategy of deploying economies of scale clearly benefited both parties since, after the operation, performance increased. This is illustrated by the company Drouot whose operating income became positive in 1984 after the Mutuelles Unies takeover (Table 2).

Table 2. Operating income and net income of Drouot (in thousand Francs)

\begin{tabular}{c|c|c|c|c|c|c}
\hline & $\mathbf{1 9 8 0}$ & $\mathbf{1 9 8 1}$ & $\mathbf{1 9 8 2}$ & $\begin{array}{c}\mathbf{1 9 8 3} \\
\text { Acquisition } \\
\text { by } \\
\text { Mutuelles } \\
\text { Unies }\end{array}$ & $\mathbf{1 9 8 4}$ & $\mathbf{1 9 8 5}$ \\
\hline $\begin{array}{c}\text { Operating } \\
\text { Income }\end{array}$ & $-59,098$ & $-2,105$ & $-291,590$ & $-99,491$, & 160,929 & 171,931 \\
\hline Net Income & 32,716 & 16,974 & $-225,159$ & 17,714 & 195,365 & 200,464 \\
\hline
\end{tabular}

Sources: Argus (Professional review specialized in insurance), 1982 to 1987.

Even in the late 1970s, some academic studies showed the positive link between insurance companies' productivity and economies of scale ${ }^{53}$, more specifically between productivity, efficiency and consolidation ${ }^{54}$.

The Axa company illustrates this feature of the insurance market. As Axa grew, its profitability increased faster than its competitors', even though the restructuring operations of 1989 and 1990 hit profitability, particularly its main branch "property and casual insurance". 
Table 3. Performance of Axa in France from 1983 to 1990

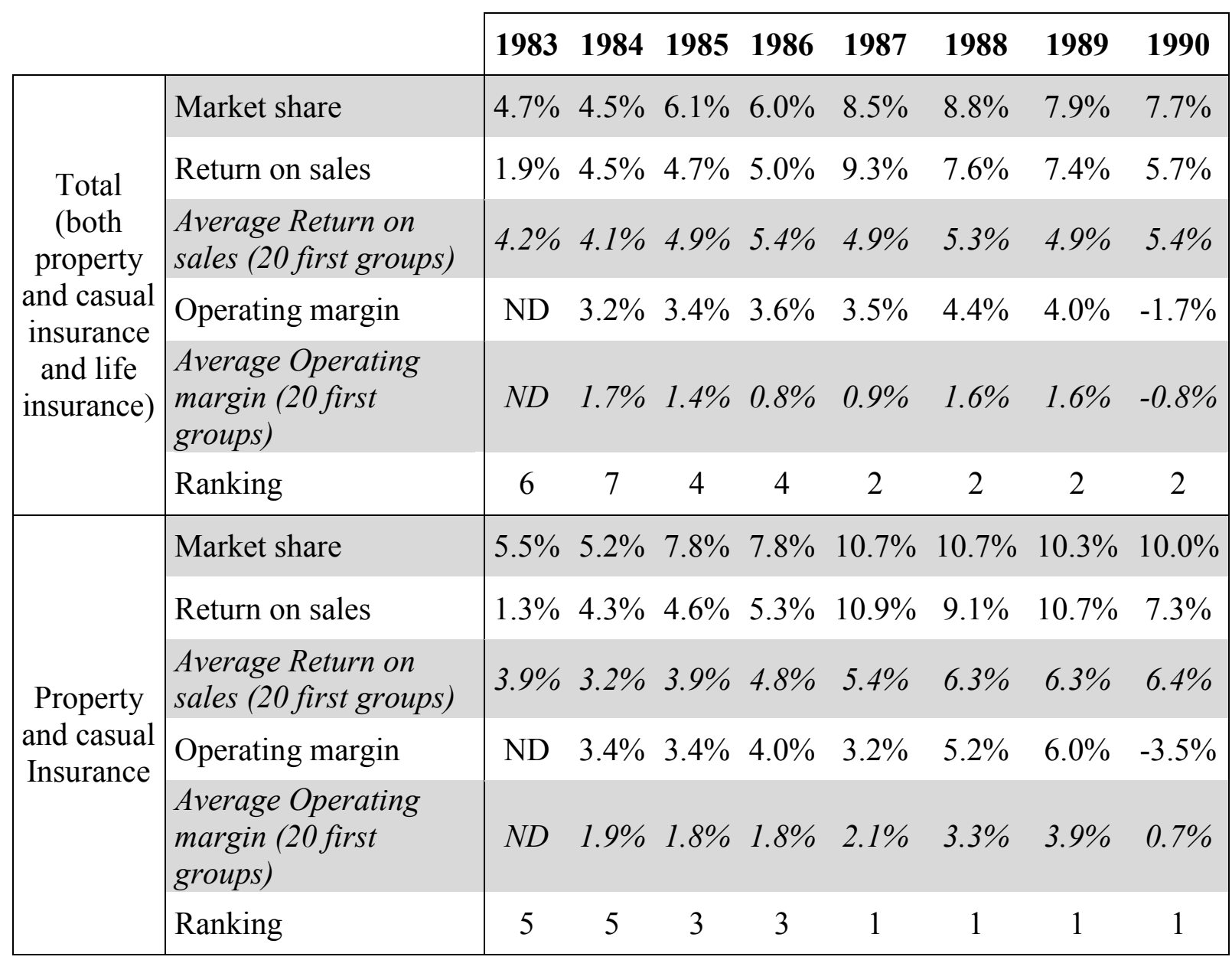

Sources: Argus, 1984 to 1991; Return on sales = Net income / Revenues; Operating margin = Operating income / Revenues

Other factors linked to regulation of the insurance market in France and Europe explain the battle for size observed in the middle of the 1980s.

From 1986, the launch of the single market in financial services (including insurance) in Europe made French companies fear foreign competition while giving them hope for market openness. In France too there was a strong trend towards privatisation, with major banks first in line (Paribas and Société Générale). Some insurance companies were privatised too ${ }^{55}$ but the major players (UAP, AGF and GAN) were State-owned. 
These privatisations put pressure on companies to increase their size either in the hope of purchasing an insurance company (Axa and Allianz respectively purchased UAP and AGF in 1997) or to become big enough to construct a large company in France.

In this context, Axa had to consolidate its external growth and integrate the companies it had purchased. The main risks and problems for Axa revolved around integrating these heterogeneous entities into what was now the Axa group as a whole.

Subsequent to the acquisition phase, Axa had to enter a phase of mergers and restructuring: the organisational structure had not in fact changed during the whole of the acquisition phase.

To avoid social conflict, C. Bébéar assured Axa employees that all companies would keep their independence. This meant that in some companies within the group, Axa played a limited role. It was so apparent that in 1986, for example, the group had three headquarters and four networks of insurance agents competing with each other, and no synergy between them. As C. Bébéar explained: "When we were Mutuelles Unies-Drouot, I thought we could co-exist as two companies in collaboration and in competition. After the acquisition of Presence [1986], it became evident that this situation had become impossible. We had to change the nature of the group" ${ }^{, 56}$. A company seminar with top management upheld the decision to restructure in 1986. The organisation was re-engineered into three entities by function: Axa brokerage, Axa insurance (in charge of the network of agents) and Alpha Insurance (specialized in life insurance). The former companies within these three entities were dissolved. From 1987 to 1991, external growth operations continued despite restructuring. In 1989, Axa gained control of La Compagnie du Midi (AGP). In short, from 1975 (C. Bébéar's directorship) to 1989 , the Axa group went from being $24^{\text {th }}$ to $2^{\text {nd }}$-largest insurance company in France. The union voucher was introduced when the restructurings first thought of in 1986 were put into practice. In the summer of 1989 , for example, the major management companies of the Axa's main insurance companies merged. The four companies 
were only simple management centres. A regionalisation process followed: the managers discovered their new work regions in early 1991. At a meeting in March 1990, employees of the Paris Area headquarters learned that the redistribution of employees among the various Paris sites had already been decided, and they would be told about their workplace after the 1991 meeting. At the same time, from May 1990 to January 1991, a new information system was set up. Some companies asked for more time to prepare, but were systematically refused: "The only way Axa Assurances will succeed is to follow the line we have drawn up to the letter" ${ }^{57}$.

The social risk for Axa was very high because restructuring causes a high degree of uncertainty among employees who constantly question their new employment conditions. Axa faced a paradox well known to human resource specialists: in the event of corporate restructuring, employee feelings of uncertainty can lead them to reject change. At the same time, it is difficult, if not impossible, to reassure employees by providing a planned schedule of changes. The success of the restructuring strategy in these situations depends on the company's ability to create a cooperative climate based on dialogue and trust. Mechanisms such as the union, that give a voice to employees, are critical. C. Bébéar understood that he needed the support of fully representative union branches in Axa in order to manage the strategy of external growth: "In small mutual companies, at the beginning, there was a close relationship between employees and Axa's union branches. Everybody knew each other. When we gained control of Drouot, it still worked fine! But when we obtained control of La Compagnie du Midi, the company was not directed by insurance professionals but by financiers; it was more of a class struggle, so Axa's union branches were isolated from other employees"58. The risk, from C. Bébéar's perspective, was the potential bringing in of conflicting social relations based on the political ideology of class struggle. In restructuring 
the group, Axa ran the risk that when a new entity was being absorbed, a negative social climate might spread throughout the whole group.

Until 1986 in fact, the acquisition of any new entity modified the social organisation of the whole only slightly. In other words, since each entity remained independent, employees did not work together anyway. However, the organisation adopted in 1987 planned to rationalise the group and re-engineer the company structure by function. The social risk was thus no longer confined to the newly purchased entities, but could spread throughout the group. With the purchase of La Compagnie du Midi in 1989, C. Bébéar had to deal with union representatives he felt were a long way from the employees he knew, and whose ideology he thought was based on class struggle.

Furthermore, the instability incurred by external growth compounded the instability of restructuring in itself, as confirmed by Claude Tendil, head of group insurance activity in France from 1989: "I am aware that all of this was brutal: we reorganized and delocalized on the day planned. [...] The climate was difficult. But we had to do it. The future of the group was at stake" $" 59$. An Axa union representative confirms this managerial interpretation in the 1980s: "There was a management strategy to agree to finance unions. At that time, there were mergers everywhere. The issue was how to accomplish the merger. With brutal solutions? Purchase a company and fire people? Bébéar offered something else and we followed him. The companies that bargained restructured more quickly. It was a management strategy"60.

Moreover, the union majorities in Axa were unstable; since the appointment of Bébéar as head of Mutuelles Unies, a local branch of CFDT was instituted, but a radical CGT is always very active ${ }^{61}$. The CFDT had a majority at the works council but only thanks to an alliance with the union of managers (CGC). Even more worrying for the head of Axa, however: deunionisation happened very fast; at Belbeuf (main site of Mutuelles Unies), for example, the 
unionisation rate dropped from $50 \%$ in 1975 to under $20 \%$ in $1987^{62}$. Axa understood the risk: it amounted to the politicisation of industrial relations by a union minority unrepresentative of the employees.

Given the low unionisation, Axa tried to maintain unions under employees' control, but the union elections failed to do this: they took place only every three years at Axa and did not result in new memberships.

As well as the risk of unrepresentative unions, Axa was worried about the risk of importing a political ideology of confederation into the company. P. Gardes, HRM of Axa when the union voucher was set up, confirms this point of view: "Unions have their uses, but you have to avoid them becoming confrontational..."63. For C. Bébéar, the union voucher dealt with "strengthening the local union and avoiding their resources coming from the confederation". C. Bebear wanted to grow discussion at company level and to do this, "union representatives have to be trained and they need resources" ${ }^{\prime \prime}$.

The social risks for the Axa group at the end of the 1980s have been well identified. Although the social climate looked peaceful, it seemed a fragile peace, and the head of Axa always had the social conflict of 1975 in mind. There were three types of risk:

The first related to Axa's external growth: the head of Axa was as worried about the postpurchase import of a radical local union as about the restructurings and hostile takeovers that contribute to employee feelings of insecurity.

The second risk related to the phenomenon of de-unionisation observed at Axa and the difficulty of maintaining a reformist union, in this case the CFDT after the election, 
The third and final risk resulted from the role of the confederations in the bargaining process; in other words, there was concern that the confederations would put pressure on the unions, resulting in their polarisation.

In order to address these risks, the head of Axa tried to maintain a social dialogue with legitimate representatives, independent of the more politicized confederation. The union voucher was a tool that created a context that encouraged social dialogue with certain actors with resources enabling them to take part in such dialogue, but these resources were determined by employee choice rather than by confederation decision. For C. Bébéar, the objective was to recreate the link between the employee and his union representative and to reduce financial dependence on the confederation. This was confirmed by a CFDT negotiator of the agreement: "That was important and the difference with other means of funding was the link with employees. The tool was created with this idea. The context was important, there were restructurings and mergers and the company's idea was: we need strong unions that are representative behind us" ${ }^{\prime 65}$.

In specific terms, funding the unions through the union voucher system would help build a relationship between Axa's union branches and the employees: "This was really about human relations. It meant that union branches had to go and see the employees and create relationships with them" ${ }^{\prime 66}$. At the same time, the union voucher system maintained good relations between the union branches and employers, as C. Bébéar adds "We actually played football with Axa's union branches, there was no problem”. From Axa's perspective, the voucher helped finance union activities resulting in union branches leaving ideological discourse aside in favour of negotiations. At the same time, it maintained the relationship between employees and unions by bringing union branches under employees' control. The challenge was to "provide the unions with financial means that they would use in strictly legal ways rather than resorting to other means. It was really important to have unions that had the 
wherewithal to negotiate. The idea was to increase social dialogue, especially since this was a time when there were a lot of strikes. What we wanted was to foster a positive relationship. (...) It was a bit of a dare, but it worked." $" 67$

It was in this way that the union voucher contributed to Axa's external growth strategy. It consolidated a peaceful social atmosphere that in turn made it possible to negotiate reorganisations and integrate new entities into the group. 


\section{Discussion}

The present article has studied the union voucher, a specific tool conceived by the CFDT trade union and set up within the insurance company Axa. In France, the union voucher, has been the topic of numerous debates on French industrial relations. Politicians from the whole political spectrum, parliamentary reports and think tanks have all suggested it as a means for advancing social dialogue. Even if the union voucher has not become widespread in French companies, the experience certainly contributed to ending the taboo of unions being funded by companies. In fact, in 1991-92, certain companies and union branches signed a number of agreements on the resources companies should make available to unions; what is new here is that these agreements include a financial component. Such agreements consist of global subsidies distributed to union branches in terms of their election results; as such, they were easily implemented. Behind the financial question, the union voucher addresses the nature of trade-unionism itself. A key motivation for adopting such mechanisms was to loosen the links between federations or confederations with their representatives inside companies. In allocating local teams with resources to act in companies, employers had high hopes of keeping at bay the political issues to which federations and confederations subscribe. In other words, the novelty of the tool lay in its break with employers' traditional strategies for weakening unions. In fact, the union voucher enhanced the influence of unions while undermining their political role, diverting it into action which could be useful to the firm's strategy. The paper looked at the strategies of Axa and the CFDT in order to understand why such a tool was implemented.

In addressing the different sides of this story, we showed that this innovation originated in the coming together of three elements specific to the French system of industrial relations (note that the union voucher was never extended to subsidiaries outside France), the reformist view of C. Bébéar, and company managerial issues. From Axa's viewpoint, implementing the 
union voucher can be understood in the light of corporate strategy. Axa was at a stage of external growth and restructuring and trying to maintain a social climate of confidence to reassure its social partners. Axa sought to depoliticise union discourse and guard against the spread of a negative, class-conflict based social climate during the purchase of new entities. The firm therefore hoped that by giving employees a voice, unions would give up their political and ideological action in favour of collective bargaining. The Axa group was able expand, acquiring the UAP when it was privatised in 1997. Its restructuring operations avoided widespread social conflict and the company is often showcased for the quality of its social dialogue. Once merely an experiment, the union voucher has endured over the last 25 years without major changes. Axa has consistently implemented the union voucher system in all its French acquisitions. Finally, this experience highlights the close links between specific corporate strategies and the entire system of industrial relations. Phillips ${ }^{68}$ has illustrated this link in the context of the reconstruction of industrial relations in the UK in the 1970s. In this case, Phillips showed that employers accepted certain new prerogatives for union representatives as long as they were compatible with the corporate strategy.

In the light of Magnusson's work ${ }^{69}$, the paper gives a concrete illustration of how our understanding of industrial relations can be enhanced by analysing business strategies. For Magnusson, the division between business history and the history of work is the consequence of an increase in knowledge. This division can be observed in the objects treated (in the industrial revolution, for example: technological changes versus changes in the organisation of work). The history of the union voucher can be considered as a typical object in the history of work. However, to understand its setting up, the business history needs analysing. Indeed, on first reading, we can look for the origins of the union voucher in the meeting between both union and management reformists. But this social context fails to explain why the union voucher was setting up at Axa but has not become widespread in other French companies. To 
find out why, we explored the actors' strategy in detail. In order to do this, we looked at the field study from a different level. While a social history of the voucher enables us to understand the ideological and political issues behind it, the business history of the voucher shows how the voucher is used both as a union goal and a company strategy. From a methodological point of view, we left aside the archives of the union confederations and instead looked at the archives of the local unions and Axa itself (in our case, with mainly oral records).

Although we cannot deny the interest of an institutional history of business tools, in the case of the union voucher, some explanations can only be found in the light of a micro-historical analysis. Indeed, the implementation of the voucher can be explained by the meeting of reformists but, above all, it had to do with the match between a company's external growth strategy and a union's growth strategy. In our opinion, it is precisely for this reason that the union voucher has not become widespread.

Through this case, we have illustrated that the history of business and the history of work are interrelated fields whose joint consideration may result in productive collaboration for future research. 
Andolfatto, Dominique, and Dominique Labbé. Histoire des syndicats : (1906-2010). Paris : Seuil, 2016.

Barthélémy, Jacques, and Gilbert Cette. Refondation du droit social : concilier protection des travailleurs et efficacité économique. Paris: La documentation française, 2010.

Berger, Allen N., Rebecca S. Demsetz, and Philip E. Strahan. "The consolidation of the financial services industry: Causes, consequences, and implications for the future." Journal of Banking \& Finance vol. 23, no.2 (1999): 135-194.

Bloch-Lainé, François, Pour une réforme de l'entreprise, Paris: Seuil, 1963.

Brucy, Guy. "Jacques Moreau". In Dictionnaire biographique. Mouvement ouvrier, mouvement social [http://maitron-en-ligne.univ-paris1.fr/spip.php?article148599, consulted June 2017]

Chatriot, Alain. "La réforme de l'entreprise". Vingtième siècle. Revue d'histoire, no.2 (2012) : $183-197$

Cummins, J. David, Sharon Tennyson, and Mary A. Weiss. "Consolidation and efficiency in the US life insurance industry." Journal of Banking \& Finance vol. 23, no.2 (1999): 325-357.

Desaegher, Caroline, L'histoire d'Axa. Paris: HM Editions, 1995.

Eyraud, François, and Robert Tchobanian. "The Auroux reforms and company level industrial relations in France". British Journal of Industrial Relations, Vol.23, no.2 (1985): 241-259.

Floquet, Mathieu, and Patrice Laroche. "The impossible transition from 'absolute monarchy' toward industrial democracy in France: the experience of workers' representatives at Schneider, 1899-1936.” Labor History vol. 55, no.1 (2014): 117-136.

Francalanci, Chiara, and Hossam Galal. "Information Technology and Worker Composition: Determinants of Productivity in the Life Insurance Industry." MIS Quarterly vol. 22, no.2 (1998): 227-41 
Freeman, Richard B., and James L. Medoff. What do unions do? New York: Basic Book, 1984.

Fridenson, Patrick. "Syndicats et réformes en France depuis 1945". Revue d'histoire moderne et contemporaine, no.5 (2009) : 75-87.

Fridenson, Patrick. "De la production au patronat" in Michel Pigenet and Danièle Tartakowski (eds) Histoire des mouvements sociaux en France. Paris : La Découverte, 2014, pp. 255-366.

Grevy Manuela. "Les accords de droit syndical." Action juridique no.96 (1992): 3-10.

Groux, Guy, and René Mouriaux. La CFDT. Paris : Economica, 1989.

Groux, Guy. "Regards sur le passé. Quelles ruptures? Quelles permanences?" in Le réformisme assumé de la CFDT, edited by Barthélémy, Martine, Claude Dargent, Guy Groux, and Henri Rey. Paris: Presses de Sciences Po, 2012.

Hadas-Lebel, Raphaël. "Pour un dialogue social efficace et légitime : Représentativité et financement des organisations professionnelles et syndicales". Report to Prime Minister, 2006.

Harris, Sidney E., and Joseph L. Katz. “Organizational performance and information technology investment intensity in the insurance industry." Organization science vol. 2 no. 3 (1991): 263-295.

Harvey, Charles, and Jon Press. "Management and the Taff Vale strike of 1900.” Business History, vol.42 no.2 (2000): 63-86.

Institut de l'entreprise. Dialogue social: l'âge de raison, 2013.

Institut Montaigne, Sauver le dialogue social, 2015.

Institut Montaigne. Reconstruire le dialogue social, 2011. 
Jacquillat, Bertrand. Nationalization and privatization in contemporary France. Stanford: Hoover Press, 1988.

Lipset, Seymour Martin. The confidence gap: Business, labor, and government in the public mind. Johns Hopkins University Press, 1987.

Le Crom, Jean-Pierre. "Le comité d'entreprise: une institution sociale instable." Centre des archives du monde du travail (1997): 173-197.

Maclean, Mairi. "Corporate governance in France and the UK: long-term perspectives on contemporary institutional arrangements.” Business History, vol.41, no.1 (1999): 88-116.

Maclean, Mairi. "New rules-old games? Social capital and privatisation in France, 19861998”. Business History, vol.50 no.6 (2008): 795-810.

Maclean, Mairi, Charles Harvey and Jon Press. "Managerialism and the Post-war evolution of the French national business system.” Business History vol.49 no.4 (2007): 531-551.

Magnusson, Lars. "Business history and the history of work - a contested relationship", Business History, vol. 56 no.1 (2014): 71-83.

Meador, Joseph W., Gerald P. Madden, and David J. Johnston. "On the Probability of Acquisition of Non-Life Insurers." The Journal of Risk and Insurance vol. 53, no. 4 (1986): 621-43.

Moss, Bernard. H. "After the Auroux laws: Employers, industrial relations and the right in France". West European Politics, Vol.11, no.1 (1988): 68-80.

Moss, Bernard H. "La réforme de la législation du travail sous la Ve République : un triomphe du modernisme ?". Le Mouvement social, no.148 (1989) : 63-91.

Noblecour, Michel. "Des accords annuels aux Mutuelles unies. La politique sociale toujours en chantier”. Le Monde, 11 August 1987. 
Pestieau, Pierre, and Chantal Pirard. « L'entreprise d »assurance: économies d »échelle et performance. » Revue d'économie financière No. 11 (1989): 93-104.

Philipon, Thomas. Le capitalisme d'héritiers, la crise française du travail. Paris: Seuil, 2007. Phillips, Jim. "Business and the limited reconstruction of industrial relations in the UK in the 1970s.” Business History vol. 51 no.6 (2009): 801-816.

Roth, Fabrice. "Gouvernement des entreprises et stratégie du dirigeant : une étude clinique dans le secteur de l'assurance”. Finance Contrôle Stratégie, vol.3, no.4 (2000): 179 - 199.

Rudel, Sylvie. "Les restructurations financières dans l'industrie française de l'assurance : à l'aube des privatisations", Revue d'économie industrielle, no.43 (1998): 83-102.

Strauss, André. "La concentration des entreprises d'assurance en France." Entreprises et Histoire vol. 3, no.72 (2013): 55-79.

Terra Nova. Renforcer la négociation collective et la démocratie sociale. 2012.

Tixier, Pierre-Eric. Mutation ou déclin du syndicalisme? Le cas de la CFDT. Paris : PUF, 1992.

Venard, Bertrand. "L'histoire du marché de l'assurance en France", Assurances et gestion des risques, vol. 8 no.1-2 (2013): 85-101.

Villette, Michel. “Axa : une croissance exponentielle (1975-1999). Entretien avec Claude Bébéar”. Gérer et Comprendre, no.69 (2002): 4-18.

Visser, Jelle. "Union membership statistics in 24 countries." Monthly Lab. Rev. 129 (2006): 38. 
Vuillermot, Catherine. "Claude Bébéar" in Dictionnaire historique des patrons français, edited by Chatriot, Alain, Danièle Fraboulet, Patrick Fridenson, and Hervé Joly. Paris: Flammarion, 2010, p. 68-70.

Wilkins, Mira. "Multinational enterprise in insurance: An historical overview." Business History, vol. 51 no 3 (2009): 334-363. 
${ }^{1}$ Lipset, The confidence gap: Business, labor, and government in the public mind.

${ }^{2}$ Philippon, Le capitalisme d'héritiers.

${ }^{3}$ Magnusson, "Business history and the history of work - a contested relationship".

${ }^{4}$ The unit value of the voucher depends on the worker's status. In 2014 , it was $€ 46.10$ for an employee and $€ 54.90$ for a manager.

${ }^{5}$ The research tools are available as a database on the CFDT website : htpp://portail.nosarchives.cfdt.fr

${ }^{6}$ Interviewed as protagonists in managerial positions when the vouchers were implemented: Axa's head, Axa's HR director, the general secretary of the CFDT, two managers from the CFDT insurance federation, the CFDT coordinator in Axa and the CGT general secretary of Banking and insurance.

${ }^{7}$ Part of the funds, max. $20 \%$, can be transferred by a union branch to its professional federation or its confederation.

${ }^{8}$ Barthélémy J. et Cette G., Refondation du droit du travail, 2010 ; Hadas-Lebel R., Pour un dialogue social efficace et légitime: représentativité et financement des organisations professionnelles et syndicales, 2006 ; Institut Montaigne, Reconstruire le dialogue social, juin 2011 ; Terra Nova, Renforcer la négociation collective et la démocratie sociale, 2012 ; Institut de l'entreprise, Dialogue social : l'âge de raison, 2013 ; Trésor-Eco, La syndicalisation en France: paradoxes, enjeux et perspectives, 2014 ; Institut Montaigne, Sauver le dialogue social, 2015.

${ }^{9}$ Former boss of large French companies (Aerospatiale, SNCF, EADS) and current chairman of the supervisory board of PSA, Louis Gallois has an important place in France as a reformist. In February 2016, during the debate on the social dialogue in France, he promoted the union voucher to increase unionization.

${ }^{10}$ Moss (1989) and Chatriot (2012) talk about a modernist trend while. Fridenson (2014) refers, for his part, to the reformative wing in opposition to the traditionalist majority.

${ }^{11}$ Chatriot, «La réforme de l'entreprise ».

${ }^{12}$ Eyraud and Tchobanian, "The Auroux reforms and company level industrial relations in France" ; Moss,

"After the Auroux laws: Employers, industrial relations and the right in France"

${ }^{13}$ Andolfatto and Labbé, Histoire des syndicats (1906-2010)

${ }^{14}$ Chatriot, op cit.

${ }^{15}$ CNPF: Conseil National du Patronat Français was the first employer organisation during the period of study. It was replaced by the MEDEF in 1998.

${ }^{16}$ Fridenson, De la production au patronat.

${ }_{17}^{17}$ Bloch-Lainé F., Pour une réforme de l'entreprise.

${ }^{18}$ Chatriot, op cit.

${ }^{19}$ Fridenson, op cit.

${ }^{20}$ Fridenson, "Syndicats et réformes en France depuis 1945".

${ }^{21}$ Brucy, "Jacques Moreau".

${ }^{22}$ Tixier, P. E., Mutation ou déclin du syndicalisme ? : le cas de la CFDT. Groux, G., \& Mouriaux, R., La

CFDT. Guy Groux Regards sur le passé. Quelles ruptures ? Quelles permanences?

${ }^{23}$ Freeman and Medoff, What do unions do, pp. 230-232.

${ }^{24}$ The list of the 5 union organisations - CFDT, CFTC, CGC, CGT, CGT-FO - resulted from a decree (31 March, 1966). Law No.68-1179 (December 27, 1968) gave unions the right to designate a union delegate in any company with at least 50 workers.

${ }^{25}$ Source: REPONSE survey, DARES (Ministry of labour), 2011.

${ }^{26}$ Visser, "Union membership statistics in 24 countries".

${ }^{27}$ This does not mean that we cannot find similar managerial strategies. For example, union discrimination also exists in France. It is a likely explanation of French workers' reluctance to unionise.

${ }^{28}$ Floquet and Laroche, "The impossible transition from 'absolute monarchy toward industrial democracy in France: the experience of workers' representatives at Schneider, 1899-1936".

${ }^{29}$ Harvey and Press, "Management and the Taff Vale Strike of 1900".

${ }^{30}$ Official journal - debates of the temporary consultative assembly - December, 131944 - p. 491 and following.

${ }^{31}$ Le Crom, "Le comité d'entreprise : une institution sociale instable".

${ }^{32}$ Op.cit., p. 25.

${ }^{33}$ Government projects for unionism, 28 September 1984, 5OBS15.

${ }^{34}$ Briefing note from the "Union Financing" working group, 2 November 1984, 5OBS15. Phrase underlined in the original.

${ }^{35}$ Briefing note from the "Financement du syndicalisme" [Union Financing] working group, 2 November 1984, 5 OBS15. 


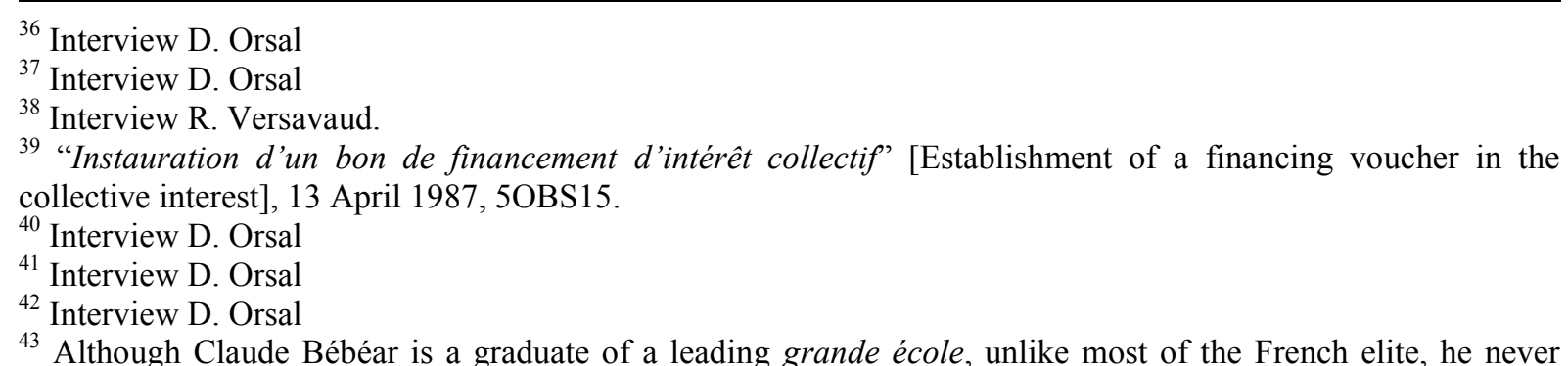

${ }^{43}$ Although Claude Bébéar is a graduate of a leading grande école, unlike most of the French elite, he never joined an institution such as the Inspection des Finances. About the French elite (and specifically C. Bébéar) see: Maclean, Mairi, "Corporate governance in France and the UK"; Maclean, M. et al. "Managerialism and the Postwar evolution of the French national business system".

${ }^{44}$ Vuillermot, "Claude Bébéar".

45 Roth, "Gouvernement des entreprises et stratégie du dirigeant". Corporate governance and management strategy

${ }^{46}$ Venard, "L'histoire du marché de l'assurance en France". The nationalisation of insurance companies was decided at the end of the Second World War. In 1946, it concerned 34 companies and half of the French insurance market.

${ }^{47}$ Maclean, M. "New rules-old games?"

${ }^{48}$ Rudel, Les restructurations financières dans l'industrie française de l'assurance : à l'aube des privatisations.

49 Strauss, La concentration des entreprises d'assurance en France ; Wilkins, Multinational enterprise in insurance: An historical overview.

${ }^{50}$ Harris and Katz. "Organizational performance and information technology investment intensity in the insurance industry."; Francalanci and Galal. "Information Technology and Worker Composition: Determinants of Productivity in the Life Insurance Industry."

${ }^{51}$ Berger, Demsetz, and Strahan. "The consolidation of the financial services industry: Causes, consequences, and implications for the future."

${ }_{52}$ Meador, Madden, and Johnston. "On the Probability of Acquisition of Non-Life Insurers."

${ }^{53}$ Pestiau and Pirard have made a literature review to measure the link between performance and economies of scale in the insurance industry. The authors enumerate about thirty studies and conclude upon a positive link. The French market is from this point of view not different from other markets. Pestieau, Pierre and Pirard. "L'entreprise d'assurance: économies d'échelle et performance."

${ }^{54}$ Cummins, Tennyson and Weiss. "Consolidation and efficiency in the US life insurance industry."

55 Jacquillat, Nationalization and privatization in contemporary France.

${ }^{56}$ Desaegher, L'histoire d'Axa, p. 170.

${ }^{57}$ J.L. Bertozzi (in charge of rationalising the information systems) quoted ibid, p. 227

${ }^{58}$ Interview of C. Bébéar.

${ }^{59}$ Desaegher, L'histoire d'Axa, p. 231.

${ }^{60}$ Interview of R. Versavaud,, CFDT negotiator for the Insurance sector between 1979 and 2013.

${ }^{61}$ Noblecourt, "Des accords annuels aux Mutuelles unies. La politique sociale toujours en chantier".

${ }^{62}$ Ibid.

${ }^{63}$ Interview of P. Gardes.

${ }^{64}$ Interview of C. Bébéar.

${ }^{65}$ Interview of R. Versavaud.

${ }^{66}$ Interview of C. Bébéar.

${ }^{67}$ Interview of Pierre Gardes, HRM Axa.

${ }^{68}$ Phillips, Business and the limited reconstruction of industrial relations in the UK in the 1970s

${ }^{69}$ Magnusson, Business history and the history of work 